\title{
ART PEDAGOGY AS MEANS FOR DEVELOPMENT OF EDUCATIONAL MOTIVATION OF STUDENTS - FUTURE TEACHERS
}

\author{
PEDAGOGIA DA ARTE COMO MEIO PARA O DESENVOLVIMENTO DA \\ MOTIVAÇÃO EDUCACIONAL DOS ESTUDANTES - FUTUROS PROFESSORES
}

\author{
LA PEDAGOGÍA DEL ARTE COMO MEDIO PARA EL DESARROLLO DE LA \\ MOTIVACIÓN EDUCATIVA DE LOS ESTUDIANTES - FUTUROS PROFESORES
}

\author{
Iskander Engelevich YARMAKEEV ${ }^{1}$ \\ Nelly Raisovna VALIAKHMETOVA ${ }^{2}$ \\ Rimma Maratovna AKHMADULLINA ${ }^{3}$ \\ Oksana Kabirovna NAZAROVA ${ }^{4}$ \\ Rustem Yahevich GIBADULLIN ${ }^{5}$
}

\begin{abstract}
The paper is devoted to the study of the impact of art pedagogy on the development of educational motivation in students. Art pedagogy is an innovative direction, the purpose of which is to create a new cognitive methodology, to overcome psychological barriers of thinking, to build the interaction between a teacher and a student based on reflective, educative and creative self-organization for intellectual and creative development. This technology is especially relevant in the capacity of an integration of art into the educational context for solving professional and pedagogical tasks of the modern educational practice. The purpose of the paper is to study the influence of art pedagogy techniques on the development of educational motivation of students - future teachers. The paper discusses the role and data of a comparative analysis of thematic planning for studying the course "History of Pedagogy and Education" in combination with the techniques of art pedagogy. It also describes the course and results of the experiment on the development of educational motivation of students using these techniques. The research methods were: theoretical analysis of scientific literature, generalization, survey, and pedagogical experiment. The findings of the research can be recommended for university and college faculty in training students - future teachers.
\end{abstract}

KEYWORDS: Educational motivation. Art. Art pedagogy. Development. Reception.

\footnotetext{
${ }^{1}$ Kazan Federal University (KPFU), Kazan - Russia. Professor of the Department of Digital and Bilingual Education and Deputy Director for Research of the Institute of Philology and Intercultural Communication. ORCID: https://orcid.org/0000-0002-1103-6469. E-mail: ermakeev@mail.ru

${ }^{2}$ Kazan Federal University (KPFU), Kazan - Russia. Associate Professor of the Department of Tatar Studies and Cultural Studies, Institute of Philology and Intercultural Communication. Candidate of Pedagogic Sciences. ORCID: https://orcid.org/0000-0002-5379-0849. E-mail: nellyv1975@mail.ru

${ }^{3}$ Kazan Federal University (KPFU), Kazan - Russia. Associate Professor of the Department of Tatar Studies and Cultural Studies, Institute of Philology and Intercultural Communication. Candidate of Pedagogic Sciences. ORCID: https://orcid.org/0000-0002-8895-7274. E-mail: akhrimma@mail.ru

${ }^{4}$ Kazan Federal University (KPFU), Kazan - Russia. Postgraduate Student of the Department of Digital and Bilingual Education, Institute of Philology and Intercultural Communication. ORCID: https://orcid.org/00000002-4979-7562.E-mail: nazarova.katt@gmail.com

${ }^{5}$ Moscow Pedagogical State University (MPGU), Moscow - Russia. Director of the Institute for Advanced Studies. ORCID: https://orcid.org/0000-0002-4825-5518. E-mail: riasmggu888@gmail.com
} 
RESUMO: $O$ artigo é dedicado ao estudo do impacto da pedagogia da arte no desenvolvimento da motivação educacional dos alunos. A pedagogia da arte é uma direção inovadora, cujo objetivo é criar uma nova metodologia cognitiva, para superar as barreiras psicológicas do pensamento, para construir a interação entre um professor e um aluno com base na auto-organização reflexiva, educativa e criativa para o desenvolvimento intelectual e criativo. Esta tecnologia é especialmente relevante na capacidade de integração da arte no contexto educacional para a resolução de tarefas profissionais e pedagógicas da prática educacional moderna. O objetivo do artigo é estudar a influência das técnicas da pedagogia da arte no desenvolvimento da motivação educacional dos alunos - futuros professores. $O$ artigo discute o papel e os dados de uma análise comparativa do planejamento temático para estudo do curso "História da Pedagogia e da Educação" em articulação com as técnicas da pedagogia da arte. Ele também descreve o curso e os resultados do experimento sobre o desenvolvimento da motivação educacional dos alunos usando essas técnicas. Os métodos de pesquisa foram: análise teórica da literatura científica, generalização, levantamento e experimentação pedagógica. Os resultados da pesquisa podem ser recomendados para professores de universidades e faculdades na formação de alunos - futuros professores.

PALAVRAS-CHAVE: Motivação educacional. Arte. Pedagogia da arte. Desenvolvimento. Recepção.

RESUMEN: El artículo está dedicado al estudio del impacto de la pedagogía del arte en el desarrollo de la motivación educativa de los estudiantes. La pedagogía del arte es una dirección innovadora, cuyo propósito es crear una nueva metodología cognitiva, superar las barreras psicológicas del pensamiento, construir la interacción entre un docente y un alumno sobre la base de la reflexión, la autoorganización educativa y creativa para la intelectualidad. y desarrollo creativo. Esta tecnología es especialmente relevante en la capacidad de una integración del arte en el contexto educativo para resolver tareas profesionales y pedagógicas de la práctica educativa moderna. El propósito del artículo es estudiar la influencia de las técnicas de la pedagogía del arte en el desarrollo de la motivación educativa de los estudiantes - futuros profesores. El artículo discute el papel y los datos de un análisis comparativo de la planificación temática para el estudio de la asignatura "Historia de la Pedagogía y la Educación" en combinación con las técnicas de la pedagogía del arte. También describe el curso y los resultados del experimento sobre el desarrollo de la motivación educativa de los estudiantes utilizando estas técnicas. Los métodos de investigación fueron: análisis teórico de la literatura científica, generalización, encuesta y experimento pedagógico. Los resultados de la investigación se pueden recomendar a los profesores universitarios y universitarios en la formación de estudiantes, futuros profesores.

PALABRAS CLAVE: Motivación educativa. Arte. Pedagogía del arte. Desarrollo. Recepción.

\section{Introduction}

The quality of training of modern teachers is the main guideline of modern education, which imposes increased requirements for the learning process as a whole and for its individual components. The change in the goals of education of students for their self-

RPGE- Revista on line de Política e Gestão Educacional, Araraquara, v. 25, n. esp. 1, p. 387-397, mar. 2021. 
development, the transition to the subject-to-subject relations and the strengthening of the role of independence in mastering knowledge determine the increasing role of educational motivation in the acquisition of professional competencies. This, in its turn, largely determines the success of this process alongside with the improvement of cognitive abilities and personal qualities, such as: responsibility, independence, and good organised nature. Despite a significant number of works devoted to educational motivation of students, there is still no complete unanimity in this matter. This is especially true concerning the influence of factors affecting the development of internal motivation, the mechanisms of its action, as well as understanding how to manage it.

One of the key issues in solving the problem of increasing the level of educational motivation of students is the choice of adequate methods and technologies for its development. Practice shows that the use of exclusively traditional technologies does not allow the effective solving of this problem. In this context, art pedagogy seems to be a promising direction as a special technology aimed at creating an enabling environment for the implementation of motives associated with achieving success and self-development of the learner's personality.

The subject of our research was the methods and techniques of art pedagogy and their ability to act as an effective means of increasing students' motivation in teaching the discipline " History of Pedagogy and Education." The purpose of this study is to identify the influence of art pedagogy techniques on the development of educational motivation of students - future teachers.

\section{Materials, methodology and methods}

Learning motivation is considered one of the factors determining the success of achieving learning goals. Its formation is influenced by the specifics of the educational system; features of the educational process; subjective characteristics of students; the specifics of the subject, the form of organization of the educational process, etc. Until recently, high hopes in terms of increasing educational motivation were assigned to information technology. But, the absolutisation of their influence is being questioned. Orientation to technical means in the development of the curriculum often prevents teachers from focusing on a creative approach to teaching. And this contradicts normative documents, where it is argued that an art-rich curriculum can help turn a school into a dynamic learning community in which teachers and students are more inclined to think critically and express themselves creatively. 
(EWING, 2018). Davis provides evidence that art can actually enhance test results with standardized tests not directly related to art. (DAVIS, 2011). As an alternative to the technocratisation of education, there is an increasing number of researchers point to the possibilities of art and teaching methods based on its use.

In this context, art pedagogy becomes relevant; it is defined as the modern direction of pedagogical science, which studies the laws, mechanisms, principles, and rules for including art in the educational context. It plays a special role for the professional training of students in pedagogical areas. When setting educational problems, orientation to future professional activities is of great importance. Students - future teachers get acquainted with the concept of pedagogical activity and its specifics from their first year of education. They know that it is creative, and mastery of the methodology of creative activity is a prerequisite for their success. In this context, the goals of the formation of professional competence coincide with the goals of the self-realization of their creative abilities when performing educational tasks based on art and teaching techniques. This conclusion is consistent with the theory of goals, the essence of which was expressed by Brophy (2013): "When students adopt learning goals (also called mastery goals or task-involvement goals), they focus on trying to learn whatever the task is designed to teach them". Performing creative tasks, students have more options for choosing activity strategies and for presenting their results. The freedom of creative embodiment of the idea allows students to rely on personal characteristics and abilities, which means to achieve better results. In this context, the arguments for studying art pedagogical techniques for us were studies on the positive impact of positive feedback on intrinsic motivation (VALLERAND; REID, 1984).

Methodological foundations of the study were: theory of motivation (DECI; RYAN, 1985); achievement goal theory (Wolters, 2004); studies on the impact of art pedagogy on the motivation and success of learning (BRYSON; HAND, 2007), (SAEED; ZYNGIER, 2012); works on the methodology of teaching art history disciplines (KAYUMOVA et al., 2019; KARKINA; SINGH; VALEEVA, 2019; KARKINA; FAJZRAHMANOVA; GLUZMAN, 2017; KARKINA; NURGAYANOVA; KAUR, 2019).

The research methods were: theoretical analysis of scientific literature, generalization, survey, and pedagogical experiment. An experimental study was conducted at the Institute of Philology and Intercultural Communication of Kazan Federal University. It was attended by 62 bachelor students of 17-18 years old studying in the direction of "Pedagogical education". The study took place when studying the course "History of Pedagogy and Education" for one 
semester. The main method was a pedagogical experiment, in which the experimental (31 people) and control (30 people) groups participated.

\section{Results}

Primary diagnostics of the developmental level of educational motivation of students in the control and experimental groups was carried out (KATASHEV, 2005). at an ascertaining stage of the experiment. Using the questionnaire and the Likert scale, students were distributed according to the levels of motivation development: 1) low level: lack of interest in the educational process, cognitive activity is manifested at the request of the teacher; 2) middle level: cognitive activity is variable; the result is interesting, but not the process of activity; 3) normal level: there is a desire for self-education and achievement of significant results in educational activities; 4) high level: conscious active cognitive activity is demonstrated; the desire for self-development is manifested. The results for the distribution of students of the experimental and control groups according to the levels of educational motivation are given in table 1 .

Table 1 - The results for the distribution of students by levels of educational motivation at a ascertaining stage of the experiment

\begin{tabular}{|l|l|l|}
\hline \multirow{2}{*}{ Motivation level } & \multicolumn{2}{|l|}{ Number of students having a given level of motivation in \% (persons) } \\
\cline { 2 - 3 } & Experimental group & Control group \\
\hline I (low) level & $22,6(7)$ & $23,3(7)$ \\
\hline II (middle) level & $32,2(10)$ & $30,0(9)$ \\
\hline III (normal) level & $38,7(12)$ & $36,7(11)$ \\
\hline IV (high) level & $6,5(2)$ & $10,0(3)$ \\
\hline
\end{tabular}

Source: Elaborated by the authors

The table shows that the distribution of students by motivation levels in the experimental and control groups did not differ significantly.

At the formative stage of the experiment, a set of classes on the history of pedagogy was developed with the inclusion of techniques of art pedagogy: theatricalization, collagemaking, educational games, literary creativity, etc. Table 2 provides an example of thematic planning for the study of the history of pedagogy in combination with recommended techniques. 
Table 2 - Thematic planning of studying the history of pedagogy in combination with recommended techniques of art pedagogy

\begin{tabular}{|c|c|c|}
\hline Item no. & $\begin{array}{l}\text { Examples of topics (modules) of the } \\
\text { discipline }\end{array}$ & $\begin{array}{l}\text { An art pedagogy technique in the process of studying the } \\
\text { topic }\end{array}$ \\
\hline 1. & $\begin{array}{l}\text { The formation of pedagogical traditions in } \\
\text { the civilizations of the Ancient East. The } \\
\text { emergence of the first schools and } \\
\text { pedagogical thought. }\end{array}$ & $\begin{array}{l}\text { Drawing up an illustrated letter of appeal on behalf of a } \\
\text { student of a school in one of the countries of the Ancient } \\
\text { East to a modern student. }\end{array}$ \\
\hline 2. & $\begin{array}{l}\text { Problems of education in the } \\
\text { philosophical teachings of Ancient } \\
\text { Greece (Socrates, Plato, Aristotle). } \\
\text { Roman philosophers and educators on the } \\
\text { topics of upbringing and education } \\
\text { (Seneca, Cicero, Plutarch, Quintilian) }\end{array}$ & $\begin{array}{l}\text { A role play-discussion, during which "students of various } \\
\text { philosophical schools" uphold the convictions of their } \\
\text { "Teacher (philosopher)" on the topic: "How to educate a } \\
\text { harmonious personality?" }\end{array}$ \\
\hline 3. & $\begin{array}{l}\text { Upbringing, education and pedagogical } \\
\text { thought during the Middle Ages }\end{array}$ & $\begin{array}{l}\text { Mini-story "I am a student of the University of Paris from } \\
\text { the Middle Ages" }\end{array}$ \\
\hline 4. & $\begin{array}{l}\text { The development of education and } \\
\text { pedagogical thought in Europe in the New } \\
\text { Age. J. A. Comenius and the formation of } \\
\text { pedagogical science. The pedagogical } \\
\text { concept of D. Locke. The concept of } \\
\text { natural human education by J.-J. Russeau. } \\
\text { French educators on the role of heredity } \\
\text { and public education in the development } \\
\text { of man (K. A. Helvetius, D. Diderot) }\end{array}$ & $\begin{array}{l}\text { Creation of artistic illustrations with comments on the } \\
\text { works of J.A. Comenius "Great didactics", J. Locke } \\
\text { "Thoughts on education", J.-J. Russeau "Emil, or on } \\
\text { education". } \\
\text { Composition of the continuation for R. Kipling's fairy tale } \\
\text { "Mowgli" about how the hero's life has developed in the } \\
\text { conditions of human society from the point of view of } \\
\text { supporters of various philosophical and pedagogical } \\
\text { concepts. }\end{array}$ \\
\hline 5. & $\begin{array}{l}\text { The development of education and } \\
\text { pedagogical thought in Western Europe of } \\
\text { the late XVIII - until the 90s of XIX } \\
\text { century. Pedagogical ideas and activity of } \\
\text { I.G. Pestalozzi. Pedagogical theory of I.F. } \\
\text { Herbart. Development of the problems of } \\
\text { developing and upbringing education by } \\
\text { A. Diesterweg. }\end{array}$ & $\begin{array}{l}\text { Role-playing game - discussion with elements of } \\
\text { theatricalization: continue the argument of scientists "What } \\
\text { is the main thing in school - education, development or } \\
\text { upbringing?" } \\
\text { Interview with A.F. Diesterweg on the topic "How to raise } \\
\text { a good teacher?" with theatrical elements }\end{array}$ \\
\hline 6. & $\begin{array}{l}\text { The main trends in reformist pedagogy at } \\
\text { the end of the 19th and beginning of the } \\
\text { 20th centuries in Western Europe and the } \\
\text { USA: }\end{array}$ & $\begin{array}{l}\text { Creation of a group collage on the topic: "How a } \\
\text { reformatory pedagogy of the late XIX - beginning of the } \\
\text { XX century able to solve the problems of the modern } \\
\text { school?", "Loving a child means ..." }\end{array}$ \\
\hline 7. & $\begin{array}{l}\text { The main trends in the development of } \\
\text { education and pedagogical thought in } \\
\text { Western Europe, the USA and East Asia } \\
\text { in the twentieth and early twenty-first } \\
\text { centuries. }\end{array}$ & $\begin{array}{l}\text { on the topic "Education } \\
\text { of the countries) }\end{array}$ \\
\hline 8. & $\begin{array}{l}\text { Upbringing, educational and pedagogical } \\
\text { thought in Russia from ancient times to } \\
\text { the nineteenth century. }\end{array}$ & $\begin{array}{l}\text { Analysis of proverbs about education and teaching in order } \\
\text { to determine their relevance or controversy for modern } \\
\text { pedagogy } \\
\text { The project of the art exhibition "The image of childhood } \\
\text { in the works of artists of various eras" } \\
\text { Staging a dialogue on the importance of education between } \\
\text { a student at the School of Mathematical and Navigation } \\
\text { Sciences (1701) and a modern student }\end{array}$ \\
\hline 9. & $\begin{array}{l}\text { ucation and pedagogical thought of } \\
\text { ssia in the XIX century. }\end{array}$ & $\begin{array}{l}\text { Compilation of a "photo album" on the theme "Traveling } \\
\text { to Famous Educational Institutions of the 19th Century." }\end{array}$ \\
\hline 10. & $\begin{array}{l}\text { Pedagogical thought in Russia in the } \\
\text { second half of the XIX century. Social } \\
\text { and pedagogical movement at the } 60 \mathrm{~s} \text { of } \\
\text { XIX century. The idea of the national } \\
\text { character of education as the basis of the }\end{array}$ & $\begin{array}{l}\text { Theatrical production "A conversation with the classics of } \\
\text { pedagogy through time" } \\
\text { Making a story on behalf of a student of the Yasnaya } \\
\text { Polyana school "My day at school" }\end{array}$ \\
\hline
\end{tabular}




\begin{tabular}{|c|c|c|}
\hline & $\begin{array}{l}\text { pedagogical system by K.D. Ushinsky. } \\
\text { The idea of "free education" by L.N. } \\
\text { Tolstoy }\end{array}$ & $\begin{array}{l}\text { Creating a multimedia clip "The image of a teacher of past } \\
\text { eras" }\end{array}$ \\
\hline 11. & $\begin{array}{l}\text { Education, school and pedagogical } \\
\text { thought of Russia in the first half of the } \\
\text { XX centuries. Theory of the collective by } \\
\text { A.S. Makarenko }\end{array}$ & $\begin{array}{l}\text { Organization and conduct of the debate: "Relations } \\
\text { between a team and an individual. What are they like } \\
\text { today?" }\end{array}$ \\
\hline 12. & $\begin{array}{l}\text { The development of the Russian school } \\
\text { and pedagogical thought in the second } \\
\text { half of the XX century. }\end{array}$ & $\begin{array}{l}\text { Creation of a graphic symbol reflecting the pedagogical } \\
\text { work of V.A. Sukhomlinsky } \\
\text { Drawing up a travel map on the work of domestic } \\
\text { innovative teachers of the } 1980 \mathrm{~s} \text {. Development of } \\
\text { advertising for the developmental education system of L.V. } \\
\text { Zankov or the system of problem education by D.B. } \\
\text { Elkonin and V.V. Davydov }\end{array}$ \\
\hline 13. & $\begin{array}{l}\text { Domestic pedagogy in the late XX - early } \\
\text { XXI centuries. Modern school and the } \\
\text { main directions of its development. }\end{array}$ & Group collage "School of the future" \\
\hline 14. & Final examination & $\begin{array}{l}\text { Creation and protection of a book trailer for the production } \\
\text { of historical and pedagogical content }\end{array}$ \\
\hline
\end{tabular}

Source: Elaborated by the authors

This was followed by the student training. The recommended techniques of art pedagogy were used in practical classes of the experimental group for each theme. Some of the techniques suggested the format of long-term projects as part of independent work. Students worked individually and in groups.

At the control stage of the experiment, a re-study concerning the educational motivation levels of students in the experimental and control groups was conducted using the previously applied methodology. The results of the distribution of students by levels of educational motivation in two groups are clearly presented in Figure 2 (see Fig.2).

Figure 2 - Distribution of students by levels of motivation

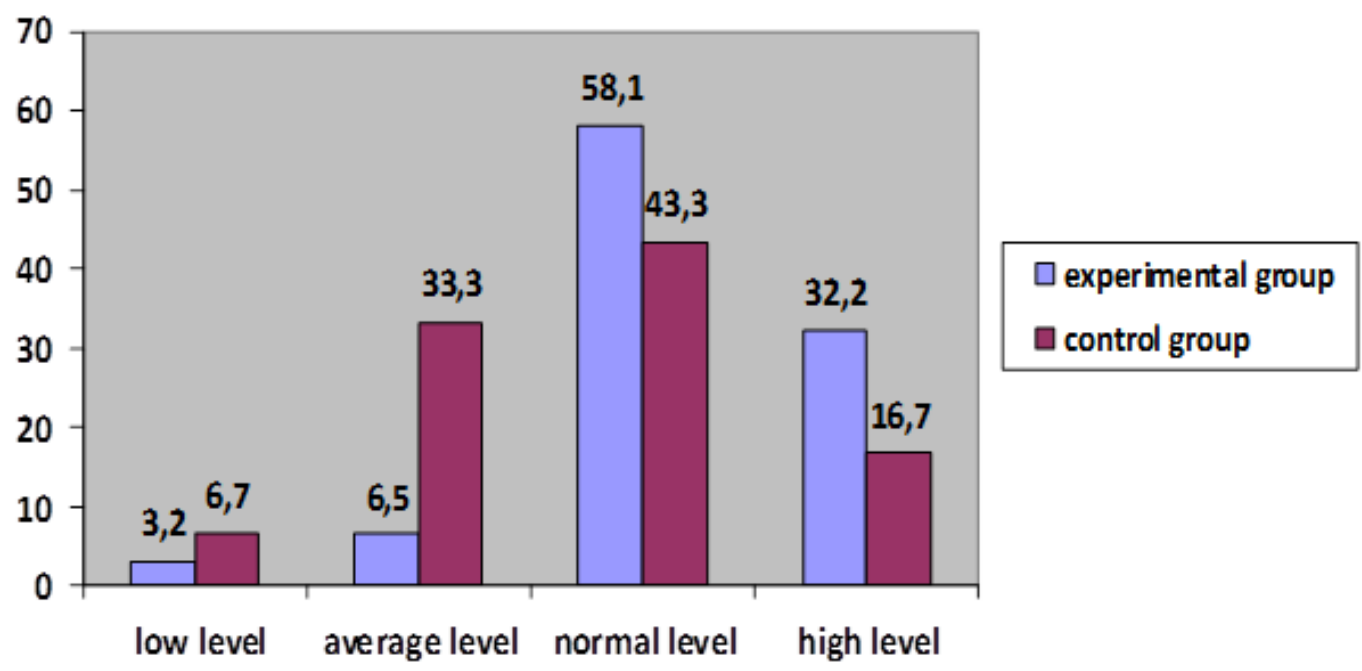

Source: Elaborated by the authors 
The diagram shows that the result in the experimental group has improved, while it slightly changed in the control group. The dynamics of changes in indicators before and after using the techniques of art pedagogy in the experimental group is graphically presented in Fig. 3.

Figure 3 - Dynamics of indicators before and after using the art pedagogy techniques in the experimental group
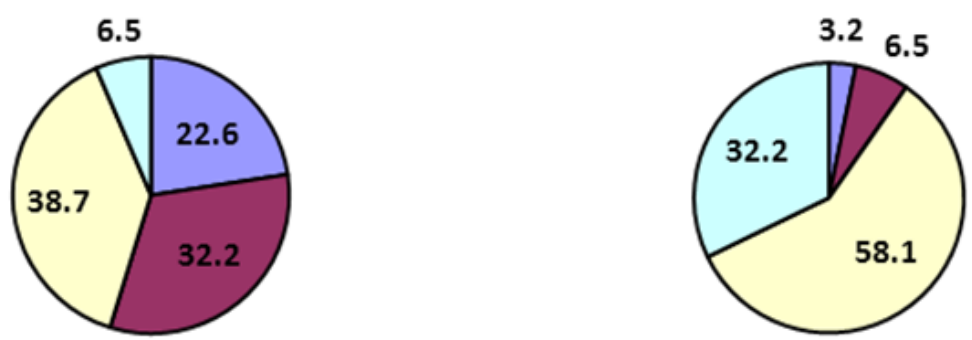

\begin{tabular}{|l|}
\hline$\square$ low level \\
$\square$ average level \\
$\square$ normal level \\
$\square$ high level \\
\hline
\end{tabular}

Source: Elaborated by the authors

The results obtained during the experiment showed positive dynamics in the development of educational motivation of students of the experimental group. Thus, we can conclude that the use of art pedagogy techniques that we identified for the development of students' educational motivation has proved its effectiveness.

\section{Discussion}

There is no doubt that educational motivation is the basis for increasing the effectiveness of training. However, in this process, priorities are given to different technologies: humanitarian communication technologies, which include art pedagogy; interactive technologies for organizing independent educational activities of students; information and communication technologies. (IGNATYEVA, 2015). There is no consensus among researchers about the impact of art pedagogy on this process. For example, Pavill (2011), in his research reports that the integration of art and nursing can open up new ways of perceiving and expressing clinical experience for medical students. Other studies have shown that medical students respond differently to artistic tasks, and $20.6 \%$ of students find little value in arts-based pedagogy. (Rieger et al., 2020). The discussion does not stop about how the relevant academic and pedagogical disciplines should be arranged in relation to the volume of academic hours allocated for their study. Analysing the problems of art and 
pedagogical education, Makarova (2015) believes that the shift in emphasis towards general education disciplines is detrimental to special subjects. One of the solutions to this problem can also be an appeal to art-pedagogical techniques in the development of pedagogical and other humanitarian disciplines. These and other facts make it necessary to continue research in the field of art pedagogy.

\section{Summary}

The paper discusses various aspects related to the relevance of the use of art pedagogy in preparing students and its impact on the development of educational motivation. The result of the study was the following: 1) the identification of techniques of art pedagogy the most effective for use in the course "History of Pedagogy" by the examples of the study of individual topics; 2) a description of the course and results of the experiment on the development of educational motivation of students using these techniques. The results can be recommended for use in the training of students - future teachers.

ACKNOWLEDGEMENTS: The work is performed according to the Russian Government Program of Competitive Growth of Kazan Federal University.

\section{REFERENCES}

BROPHY, J. E. Motivating students to learn. Routledge, 2013.

BRYSON, C.; HAND, L. The role of engagement in inspiring teaching and learning. Innovations in education and teaching international, v. 44, n. 4, p. 349-362, 2007.

DAVIS, J. H. Why our high schools need the arts. New York, NY: Teachers College Press, 2011.

DECI, E. L.; RYAN, R. M. Cognitive evaluation theory. In Intrinsic motivation and selfdetermination in human behavior (pp. 43-85). Springer, Boston, MA. (1985).

EWING, A. R. Making a difference in learning through arts-rich pedagogy. 2018.

IGNATYEVA, I. The trend of technologisation of modern education (the use of humanitarian technologies). Procedia-Social and Behavioral Sciences, v. 214, p. 606-613, 2015.

KARKINA, S. V.; FAJZRAHMANOVA, L. T.; GLUZMAN, A. V. Subject-oriented approach in the professional formation of the future music teacher. Journal of History Culture and Art Research, v. 6, n. 4, p. 1071-1077, 2017. 
KARKINA, S. V.; NURGAYANOVA, N. K.; KAUR, M. Traditional music and poetry of the tatars-mishars: Modern forms of existence. Humanities \& Social Sciences Reviews, v. 7, n. 6, p. 477-480, 2019.

KARKINA, S. V.; SINGH, B.; VALEEVA, R. A. Signature pedagogies of music learning by the Means of MOODLE across Russian and Indian Approach. In: INTERNATIONAL CONFERENCE ON TECHNOLOGICAL ECOSYSTEMS FOR ENHANCING MUlTICULTURAliTY, 7., 2019, León. Proceedings [...]. León, Spain, 2019. p. 575-581

KATASHEV, V. Pedagogy of higher education. Kazan, 2005. 395 p.

KAYUMOVA, R.; DYGANOVA, E.; BATYRSHINA, G.; BAGHDASARYAN, A. Formation of visual culture in teenagers by teaching them photographic art. International Journal of Innovative Technology and Exploring Engineering, v. 9, n. 1, p. 5130-5133, 2019.

MAKAROVA, K. Prospects for the Development of Art Pedagogical Education: the Case of the New Profile "Art of the book". Procedia-Social and Behavioral Sciences, v. 214, p. 305$318,2015$.

PAVILL, B. Fostering creativity in nursing students: a blending of nursing and the arts. Holistic Nursing Practice, v. 25, n. 1, p. 17-25, 2011.

RIEGER, K. L.; CHERNOMAS, W. M.; MCMILLAN, D. E.; MORIN, F. L. Navigating creativity within arts-based pedagogy: Implications of a constructivist grounded theory study. Nurse Education Today, v. 91, 104465, 2020).

SAEED, S.; ZYNGIER, D. How motivation influences student engagement: a qualitative case study. Journal of Education and Learning, v. 1, n. 2, p. 252-267, 2012.

VALLERAND, R. J.; REID, G. On the causal effects of perceived competence on intrinsic motivation: A test of cognitive evaluation theory. Journal of Sport and exercise Psychology, v. 6, n. 1, p. 94-102, 1984.

WOLTERS, C. A. Advancing achievement goal theory: using goal structures and goal orientations to predict students' motivation, cognition, and achievement. Journal of Educational Psychology, v. 96, n. 2, 236-250, 2004. 


\section{How to reference this article}

YARMAKEEV， I. E.; VALIAKHMETOVA， N. R.; AKHMADULLINA， R. M.; NAZAROVA, O. K.; GIBADULLIN, R. Y. Art pedagogy as a means for development of educational motivation of students - future teachers. Revista on line de Política e Gestão Educacional, Araraquara, v. 25, n. esp. 1, p. 387-397, mar. 2021. e-ISSN:1519-9029. DOI: https://doi.org/10.22633/rpge.v25iesp.1.14975

Submitted: 06/11/2020

Required revisions: 18/01/2021

Approved: $23 / 02 / 221$

Published: $01 / 03 / 2021$ 